\title{
FEDERAL JURISDICTION AND THE REVISION OF THE JUDICIAL CODE
}

\author{
HERBERT WECHSLER*
}

The proposed revision of the Judicial Code, ${ }^{1}$ approved by the House of Representatives, ${ }^{2}$ is now before the Judiciary Committee of the Senate. In form it is a bill to revise Title 28 of the United States Code and to enact it as law rather than presumptive evidence of law. In substance, though the bill advances many changes in existing provisions, it envisages no major alteration in the present distribution of judicial power between national and state courts. If there is need, as has been often said, for searching re-examination of the bases of the district court jurisdiction, ${ }^{3}$ it will survive enactment of this draft.

To say this is to appraise but not to criticize the pending bill. Its form and substance were largely predetermined by its origin in the title-by-title re-examination of the United States Code committed to the House Committee on the Revision of the Laws, ${ }^{4}$ the duties of which were but recently absorbed by the Judiciary Committee. Such an enterprise presupposes formal and interstitial improvement as the maximum objectives. Moreover, a bill of this scope, whatever its source, can hardly be accepted by the Congress on any other ground than its faith in the competence of the revisers and in the alertness of the bar to call attention to questionable details. To weight the draft with proposals posing controversial issues might well assure that no bill would be passed at all. These were, at least, the premises of the revisers. ${ }^{5}$ Within their limits they have not by any means produced a timid work.

This is not the place for a report on all the changes that the bill would work in point of substance-though there is room for larger explanation everywhere than that presented in the Reviser's notes. ${ }^{6}$ The wealth of small detail that governs the organization, personnel, and administration of the federal courts lies, for the most

- A.B. 1928, College of the City of New York; LL.B. 1931, Columbia University. Professor of Law, Columbia Law School; member, Advisory Committee on Rules of Criminal Procedure, United States Supreme Court; formerly Assistant Attorney General of the United States.

${ }^{2}$ H. R. 3214, 8oth Cong., Ist Sess. (1947); see H. R. REP. No. 3o8, 8oth Cong,, Ist Sess. (1947); Hearings before Subcomnittee No. I of the Committee on the ludiciary of the Howse of Representaticus on H. R. I600 and H. R. 2055, 80th Cong., Ist Sess. (1947). The bill is discussed in Note, 60 Harv. L. REv. 424 (1947).

${ }^{2} 93$ Cong. Rec. 8559 (July 7, 1947).

${ }^{3}$ See, e.g., Frankfurter, Distribution of Judicial Power Between United States and State Courts, 13 Corn. L. Q. 499 (1928); McCoranck and Chadbourn, Cases on Federai Courts viii-jx (1946).

'See Revision of the Federal Judicial Code (Committee Print, r945); H. R. Rep. No. 2646, 79th Cong., 2d Sess. (1946) (Report of Committec on Revision).

See Hearings, supra note $\mathrm{I}$, at $\mathrm{Ir}$.

-The notes are presented as an Appendix to H. R. Rep. No. 308, supra note 1. 
part, well beyond the scope of this symposium. It is enough to say that there is major gain in the redrafting of these old provisions, their adaptation to the superseding sections of the Rules, and ordered concentration in a single place. There is, however, room for close attention to the aspects of the draft that touch the definition of the federal jurisdiction. Where changes have been made, to what extent are they responsive to the problems? What is required that has here been left undone?

\section{The Business of the Federal Courts}

The data is at hand to show in broadest outline the use to which we put the federal judicial institution. The cases filed in lower federal courts in fiscal 1947 showed these totals: ${ }^{7}$

CASES WHERE THE FEDERAL GOVERNMENT IS A PARTY

Criminal prosecutions..................................... 35,694

Civil actions by United States in district courts................. 23,822

Actions against the United States or federal agencies in district courts. . . . . 5,742

Review of federal boards and commissions in courts of appeals......... 506

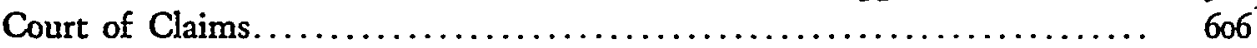

Customs Court........................................ 10,567

ALL OTHER CASES

Admiralty .................................. 1,766

Arising under federal law

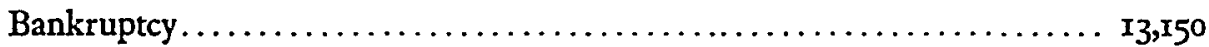

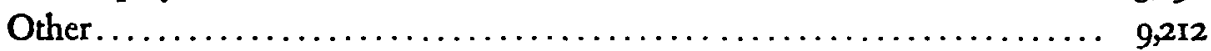

Diversity of citizenship............................. 8,692

We must note a relatively small addition to these figures for two other groups of cases: those filed in the $\operatorname{Tax}$ Court $^{8}$ and those seeking review by the Supreme Court of state adjudications claimed to present substantial federal questions.

The totality of federal judicial business involves, then, well above 100,000 new cases per annum, apart from duplications on appeals within the system of the national courts. The business is derived from three main sources: ( $\mathrm{I}$ ) cases in which the national government is itself a party; (2) cases between private parties that call for application of the federal law; (3) controversies between citizens of different states. To what extent are these the cases on which federal judicial energy should be expended? Should any be remitted to state courts? Should any be included that are now left to the state tribunals? These are the questions posed to Congress in reviewing the delineation in the statutes of the jurisdiction of the federal courts.

There have been periods in our history when questions such as these were marked

\footnotetext{
'See Annual Report of the Director of the Administrattye Office of the United States Courts, Tables B 3, C 2, D 2, F ra, G 1, G 3, G 4 (I947).

- The Report of the Commissioner of Internax Revenue for fiscal 1946 shows (Table 123, $p$. 213) dispositions for that year in 2,728 cases. No later data is at hand.
} 
with deepest tension in our federalism. It is a sign of our advance that today they do not often kindle conflict of this kind. Whatever view is held as to the proper scope of federal activity, no major challenge will be offered to the proposition that the federal law must be supreme within its sphere. We have, in short, perceived that the right focus of the problem of federal-state relationships is substantive, not adjective. There is an ever-present issue as to how much can or should be ordered or attempted by the federal authority. There is no issue on the point that what the federal law affirms-the powers, rights, or duties grounded in its sanction-must be sustained with reasonable efficiency. Thus Congress has at least one stable measure for assessing the sufficiency of juridictional determinants: they must provide an adequate machinery for vindication of the federal law.

It does not follow from acceptance of this principle that every case that has a federal ingredient must be drawn to an initial federal forum. The alternative remains to let such cases take their course with others through the state procedures, subject to review by the Supreme Court if claims asserted under federal law have been denied. This method has the virtue of preserving for final resolution by state agencies any issues in the case that turn upon state law; the more numerous or weightier such state ingredients, the more important it may be to have them first determined by state courts. Initial state adjudication also tends, however, to give the states the final voice on any federal questions, for review by the Supreme Court, even when the parties can afford to seek it, can never function on a quantitative basis. It is and ought to be confined to cases of the most pervasive import, selected very largely in the discretion of the Court. The problem is, therefore, to determine when relatively final state determination involves least risk of error upon federal matters, or when such risk as it involves is counterbalanced by the disadvantages of an original jurisdiction in the federal courts. Beyond this lies the special problem of diversity jurisdiction, involving federal adjudication of cases that have only state ingredients and thus present in the most aggravated form the danger that the national tribunals may misapply state law.

It is, of course, to state the issues in the broadest terms to put the problems in this way. No formulae for jurisdiction can reflect with full resiliency the complicated values of our federalism. There is no perfect separation between factors that are relevant to jurisdiction and those that should have bearing only on the manner of its exercise. However well devised the general standards, correctives will be needed in particular situations that are not readily articulated in a statutory rule. But the sum of federal adjudication should represent as prudent use as we can make of the important national resources represented by the federal courts. To what extent is this accomplished by the present statutes and how will it be furthered by the draft?

We need not pause upon provisions dealing with appellate jurisdiction. The Judges' Bill gave the solution for the Supreme Court and, though its language has 
been modified, the substance is not altered by the draft. ${ }^{9}$ The problems of the circuit courts pose narrow issues, of which the final-judgment rule suggests a prime example; $;^{10}$ changes in this area are rightly left to the initiative of the Judicial Conference, well equipped to see the situation as a whole. The focus of congressional attention ought to be the lower courts. The jurisdiction and authority conferred on them are the debatable determinants of the uses of the federal courts.

\section{II}

\section{The Federal Government as Litigant}

There is the smallest question as to jurisdiction in the largest category of cases that receive initial federal determination: those where the United States or any of its agencies is party to the litigation. Criminal prosecutions under federal statutes should certainly be instituted only in a federal court, within the range of the pro tections granted by the Bill of Rights. When civil redress is open to the Government, it should be free to seek it in a court of the United States, though there are situations where the litigating officers may well prefer to seek the remedy in state courts. To the extent that relief can be awarded against the United States or agents of the Government, its propriety and measure are quite plainly the prime business of a national court. In all these cases the law to be applied is normally exclusively federal. Even when there are state questions, the impact of state law upon the interests represented by the Government is the subject of a national concern.

Responsive to considerations of this order, existing law provides exclusive jurisdiction in the district courts of "all crimes and offenses cognizable by the United States," and opens those courts to all civil actions "brought by the United States, or by any officer thereof authorized by law to sue." The draft attempts no change of substance in this area. ${ }^{11}$ Nor does it purport to alter the prevailing situation with

- Sce H. R. 3214, \$\$1252-1257, 2101-2106; cf. Act of Feb. 13, I925, c. 229, §14, 43 STAT. 936, 942; Felix Frankfurter and James M. Landis, The Business of the Supreme Court 255 et seq. (I927).

Pravisions on the composition of the Supreme Court are: $\$ \$ 1-6,42$; on court officers and employees, $\$ \$ 671-676$; on rule-making authority, $\$ \$ 2071-2073$. The bill retains the present rule that six justices are required for a quorum $(\$ I)$ and provides $(\$ 2109)$ that when a qualified quorum is unavailable in a case on direct appeal from a district court, the Chief Justice "may order it remitted to the court of appeals for the circuit including the district in which the case arose, to be heard and determined by that court either sitting in banc or specially constituted and composed of the three circuit judges senior in commission who are able to sit, as such order may direct." In other cases which lack a quorum, "if a majority of the qualified justices shall be of opinion that the case cannot be heard and determined at the next ensuing term," the bill requires an order of affirmance as in cases of equal division. These provisions build in part on special Congressional precedent. See 58 Srar. 272 (1944), 49 U. S. C. $\$ 45$ (Supp. 1946). They pose none the less the question why decision by a Supreme Court of five justices is not preferable to final determination by a circuit court of three, or to no federal adjudication at all.

${ }^{10}$ H. R. 3214, \$\$1291, 1292; see, e.g., Musher Foundation v. Alba Trading Co., r27 F. 2 d 9 (C. C. A. 2d 1942); Zalkind v. Scheinman, 139 F. $2 d 895$ (C. C. A. 2d 1943); cf. Reeves v. Beardall, 3 I6 U. S. 283 (I 942 ).

${ }_{11}$ The clause providing jurisdiction in criminal cases is, however, transferred from Title 28 to the pending revision of Title 18 (H. R. 3190, 8oth Cong., Ist Sess. \$323I), a change of merely formal import if, as is assumed, that Title will be first enacted. The present clause for civil cases (see $28 \mathrm{U}$. S. C. $54 \mathrm{I}(\mathrm{I})(1940)$ ) is made a separate section ( $\$$ 1345) with only verbal changes, including proper reservation of the situations where a special statute has decreed a forum other than the district court. 
regard to remedies against the Government, though it incorporates in Title 28 some provisions drawn from other titles dealing with the special courts. ${ }^{12}$ Consent to suit against the United States would be maintained in cases where it now is granted. ${ }^{13}$ There would be no change in present methods of reviewing action of administrative agencies where the special statutes have defined them. ${ }^{\mathbf{1 4}}$ In other situations, the uncertainties and difficulties that beset the remedies against federal officialdom would be unaffected if the bill were law. One would not urge that this bill is the proper setting for a general revision of the remedies against the Government. There are, however, aspects of the problem that are directly raised by Title 28 and should, it seems to me, receive attention here.

I. Neither the present statute nor the draft vests in the district courts a general authority in actions against agencies or officers of the United States based on a claim of illegality in conduct under color of their office. Apart from situations where a method of judicial review is particularly prescribed by statute, the only grant of jurisdiction that includes such cases is that in matters "arising under" the Constitution or the laws. ${ }^{15}$ This mode of treatment introduces limitations, such as jurisdictional amount and the rule that federal questions must appear without anticipation of defenses, ${ }^{16}$ that have no place in actions against federal officials, which are necessarily of federal concern. Where the relief demanded is injunctive, a defect of federal authority may mean a total lapse of jurisdiction, for it is still doubtful whether state courts are empowered to restrain the action of a federal official taken under color of federal law. ${ }^{17}$

The draft gives some attention to the issue in providing that all actions or prosecutions in state courts against "any officer of the United States or any agency thereof, or person acting under him, for any act under color of such office or on account of any right, title or authority claimed under any Act of Congress for the apprehension or punishment of criminals or the collection of the revenue" may be

12 Customs Court: H. R. 3214, $\$ 251-255,871,872,1581-1583,2631-2641$; Tax Court: $\$ \$ 271-277$ (and alternative $\$ \$ 272$ and 273 in Reviser's notes, H. R. REP. No. 308, supra note 1 , at A 40), 911, r621, 2551-2560. For companion provisions drawn from Title 28, see: Court of Claims: $\$ \$ 171-175$, 791-795, 1491-1504, 2501-2520; Court of Customs and Patent Appeals: $\$ \$ 211-216,831-834$, 1541$1543,260 \mathrm{x}-2602$.

${ }^{13}$ See especially H. R. 3214, $\$ 1346,1347$, r 49r, I495-1496, 1498, 1504, 2674.

${ }^{14}$ The rule of Dobson v: Commissioner, 320 U. S. 489 (1943), would, however, be abolished by an amendment made upon the passage of the bill in the House ( $\$ 1294)$ providing that judgments of the Tax Court shall be reviewable in the circuit courts of appeals "in the same manner and to the same extent as decisions of the district courts in cases tried without a jury." 93 Cong. Rec. 8550 (July 7 , 1947).

${ }_{10}$ Judicial Code $\$ 24,28$ U. S. C. $\$ 4$ I(1940); H. R. 3214, \$\$1331, 1336, 1337, 1339, 1340, 1343(r).

${ }^{10}$ See, e.g., Louisville \& Nashville R. R. v. Mottley, 2 I I U. S. 149 (xgo8); cf. Bell v. Hood, 327 U. S. 678 (1946).

17 The question was briefed and argued but left open by the Court in Brooks v. Dewar, 313 U. S. 354 (194I). Cf. Warren, Federal and State Court Interference, 43 Hanv. L. Rev. 345, 358 (r930); In re Turner, Ir9 Fed. 231 (S. D. Iowa 1902); Lewis Publishing Co. v. Wyman, 152 Fed. 200 (E. D. Mo. 1907); Armand Schmoll, Inc. v. Federal Reserve Bank, 286 N. Y. 503, 37 N. E. 2 d 225 (194I). 
removed by the defendants to the district court.1s This is a proper extension of the removal now allowed to a small number of officials ${ }^{19}$ whose cases stand upon no different ground than others. Taken alone, it helps to meet the problem from the point of view of the official who may remove in any proper case. But it does not meet the problem of the plaintiff who both before and after the removal must establish, to maintain the action, that there was a jurisdiction in the state court. ${ }^{20}$ The solution is to vest a jurisdiction in this type of case in district courts without regard to other factors. With this change made, the bill might well go further and resolve the mooted question on injunctions by providing that relief of this variety may be decreed against a federal officer only by the federal courts.

It should be added that in no case should state law provide the measure of the liability of federal officials acting under honest color of their office-unless the federal law itself submits their conduct to the governance of state authority, as often is the case. What remedies should be accorded against federal action is, it seems to me, a problem for the federal law and, in the silence of the Congress, a law determined by the federal courts. This, as I suggest hereafter, is an aspect of a larger problem that should be dealt with in the draft. ${ }^{21}$

2. A separate basis for the jurisdiction in actions against federal officials based on their official conduct should be accompanied by the elimination of procedural restrictions that are anomalous in cases of this kind. Apart from special statutory remedies, such cases now are treated like any other personal action under federal law. The venue is the district of the residence of the defendants. ${ }^{22}$ It is there or in that state that process must be served. ${ }^{23}$ There is uncertainty as to the parties in the official hierarchy who must be made defendants. ${ }^{24}$ The suit will fail if the defendants who are indispensable cannot all be sued in the same district. ${ }^{25}$

These problems should be met. Where there is substantive basis for a suit against an agency or officer of the United States in relation to official conduct,

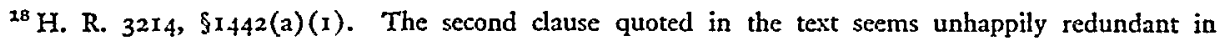
view of the generality of the first.

Officers of the courts and of Congress are the subject of separate provisions in $\$ 1442(2)(3)$ and (4). A "property holder whose title is derived from any such [federal] officer, where such action or prose-

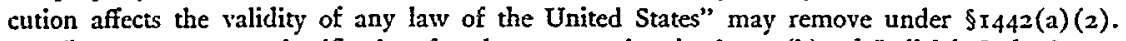

There scems scant justification for the preservation in $\$ 1442$ (b) of Judicial Code $\$ 34,28 \mathrm{U}$. "S. C. $577(1940)$.

${ }^{10}$ Judioial Code $\$ 33,28$ U. S. C. $\$ 76$ (1940); Articles of War 117, 1o U. S. C. \$1589 (1940); see Maryland v. Soper, 270 U. S. 9, 36 (1926); but of. Gay v. Ruff, 292 U. S. 25 (1934).

${ }^{20}$ The doctrine is that a defect in state court jurisdiction survives on removal since in such case the federal authority is derivative. See Minnesota v. United States, 305 U. S. 382 (1939); Lambert Run Coal Co. v. B. \& O. R. R., 258 U. S. 377 (r922); Lewis Publishing Co. v. Wyman, sttpra note I7. But cf. Freeman v. Bee Machine Co., 3 r9 U. S. $44^{8}$ (r943).

${ }^{21}$ See Part V, infra. Cf. Bell v. Hood, 327 U. S. 678 (1946), 7 I F. Supp. 813 (S. D. Cal. I947),

22 Judicial Code $\$ 51,28$ U. S. C. $\$ 112$ (1940); H. R. $3214, \$ 139 \mathrm{r}$.

23 FED. R. Civ. P., 4 (f).

${ }^{24}$ See, e.g., Williams v. Fanning, 68 Sup. Ct. I88 (U. S. 1947); Webster v. Fall, 266 U. S. 507 (1925); Brooks v. Dewar, supra note r7; Varney v. Warehime, I47 F. 2d 238 (C. C. A. 6th I945); 2 Moore's Federal Practice 2156 (i938); Notes, 50 Harv. L. Rev. 796 (1937), 32 Ill. L. Rzv. 99 (1937), 50 Yale L: J. 909 (194I), 158 A. L. R. I126 (1945).

${ }_{25}$ Cf. Camp v. Gress, 250 U. S. 308 (1919). 
action should lie in any district where the conduct has its impact and the process of that court should run to all defendants, wherever they are found. The parties will then present no problem, for there will be no difficulty in combining both the head of the department and the subordinates, if any, who are immediately involved. There is sufficient precedent for such procedure under special statutes. ${ }^{20}$ The principle should be accorded general scope. ${ }^{27}$ The defense in cases of this kind is always made through the official channels and is not hampered by the choice of venue. If the location of the trial should pose a problem to the Government, as if it would remove an officer of some importance from the scene where he performs his duties, the draft now gives the right solution in permitting venue to be changed. ${ }^{28}$

A shift to other districts of actions now brought only in the District of Columbia should not, of course, produce a change in the nature or extent of remedies available. There are, however, instances where the territorial authority of the district court within the capital may be broader than the powers of a district court within a state. ${ }^{20}$ The differences should be eliminated by providing that all district courts have the authority to grant all remedies against federal officials appropriate to the judicial power, in accordance with the principles of law..$^{30}$ Needless to say, no territorial prop is needed to sustain the federal authority to redress excesses of national officers acting under national law.

3. The defense of sovereign immunity, so commonly adduced in actions against Government officials founded on allegedly illegal conduct, should be reconsidered by the Congress with a view to limitation of its scope. Such limitation has, indeed, been the progressive consequence of decisions of the Supreme Court, which recently has stated the criterion as whether "the judgment sought would expend itself on the public treasury or domain, or interfere with the public administration." ${ }^{31}$ This

${ }^{20}$ See, e.g., Trading With the Enemy Act $\$ 9,40$ STAT. 418 (1917), 50 U. S. C. App. $\$ 9(1940)$ (actions against Alien Property Custodian); Nationality Act of 1940 \$503, 54 STAT. 1171, 8 U. S. C. $\$ 903$ (1940) (suit for declaration of United States nationality where right or privilege of national denied by executive authority).

${ }^{27}$ It should also be applied to petitions for habeas corpus which now become moot if there is $a$ * change in the subordinate custodian, as when the petitioner is moved out of the district. See United States ex rel. Innes v. Crystal, 3 I9 U. S. 755 (I943); United States ex rel. Lynn v. Downer, 322 U. S. 756 (1944). But cf. Ex parte Endo, 323 U. S. 283,304 (1944).

${ }^{28} \mathrm{H}$. R. 3214, $\$ 1404(\mathrm{a})$ : "For the convenience of parties and witnesses, in the interest of justice, a district court may transfer any civil action to any other district or division where it might have been brought." The provision is not, however, without its own problems. See Braucher, The Inconvenient Federal Forsum, 60 HARv. L. REv. 908, 930 (1947).

${ }^{20}$ See Kendall v. United States, 12 Pet. 524 (U. S. 1838 ) (mandamus). The problem is, however, of narrow import in view of the breadth of federal equitable relief (see Note, 38 CoL. L. REv. 903 (1938)), and the possible impact of $\S 10(b)$ of the Federal Administrative Procedure Act, 5 U. S. C. A. 5roog(b) (Supp. 1946). But of. Land v. Dollar, 330 U. S. 73I, 734 (1947), where the action to recover stock allegedly illegally withheld was brought under the District of Columbia Code.

${ }^{30}$ The provision ( $\$ \times 651$ ) that "all courts established by Act of Congress may issue all writs necessary or appropriate in aid of their respective jurisdictions agreeable to the usages and principles of law" will undoubtedly be taken as declaratory of previous authority, despite the climination of the language of the older sections that produced their restrictive implications. See Judicial Code, $55234,261,262,28$ U. S. C. $\$ \$ 342,376,377$ (1940).

${ }^{31}$ See Land v. Dollar, supra note 29, at 738; cf. Mine Safety Co. v. Forrestal, 326 U. S. 371 (1945); Aircraft \& Diesel Corp. v. Hirsch, 33 I U. S. 752 (1947). 
is a plainly narrow standard but it has uncertain reach, the more so for the contradictions in the earlier decisions. ${ }^{32}$ The matter is complex but not beyond the possibility of clarification by legislation. There is no place for any doctrine of immunity that serves to insulate national executive officials against liability for injuries threatened or inflicted by their illegal action. Where the Congress has specifically withdrawn a remedy or has prescribed some other method by which it should be sought, that action is itself the governing law and needs no aid from any further concept of immunity. It should suffice, therefore, to limit the immunity to cases where relief cannot be granted unless judgment runs against the United States as such, as distinguished from its officers, and consent to suit has not been granted by an act of Congress. This would, of course, protect the fisc and other public property where title is admittedly in the United States. To the extent that it withdraws immunity it will not affect such other preconditions of relief as standing to complain, exhaustion of administrative remedies, justiciable controversy, or ground for equitable intervention, which have developed in administrative law; nor will it interfere with other proper variations in the extent or measure of judicial review. It will reduce one barrier but nothing more. If this is, none the less, too simplistic a proposal, those who would attack it should at least be called upon to show their cause.

4. One of the few specific provisions in Title 28 for judicial review of federal administrative action is that made for suits to restrain enforcement of orders of the Interstate Commerce Commission, which must be heard by a three-judge court whose judgment is reviewable directly by the Supreme Court. ${ }^{33}$ Bills approved by the Judicial Council ${ }^{34}$ would alter this plan of the Expediting Act, providing in this and other cases following the system a circuit court review upon the record made by the commission. This proposal to apply the common method of judicial supervision of the federal administrative agencies has been the subject of a separate hearing. Its adoption is to be expected and will, it seems to me, improve the Code.

\section{III}

\section{The Vindication of Federal Rights}

The task of vindicating federal rights and duties is not confined to cases where the Government is party litigant. A host of statutes in creating federal causes of action specially provide for their enforcement in the district courts. ${ }^{35}$ Apart from

${ }^{32}$ See Land v. Dollar, supra note 29, at 736-738; Neher v. Harwood, 128 F. 2 d 846 (C. C. A. 9th 1942); Block, Suits Against Government Officers and the Sotereign Immutity Doctrine, 59 Harv. L. REv. 1060 (1946).

${ }^{33}$ Judicial Code $\$ 24(28), 28$ U. S. C. $\$_{41}$ (28) (I940); 38 STAT. 220 (I913), 28 U. S. C. $\$ 47$ (I940). H. R. $3214, \$ \S 133^{6}, 2321-2325$. The bill unifies the procedure for the composition of the three-judge court in this and other cases $(\$ 2284)$.

${ }^{34}$ H. R. 1468, 1470, 80th Cong., ist Sess. (1947); see Annual Report of the Director of the Administrative OfFice of the United States Courts 23-24 (1947); Report of the ludicial Conference, 92 L. Ed. 125, 134 (1947) (disapproving procedural amendments proposed by the Department of Justice).

${ }^{35}$ See the extensive list of such provisions in the Reviser's notes ( H. R. REP. No. 308, pp. A rr6117). The consequence of this development has been to destroy the plan of $\$ 24$ to picture all the bases 
these particular provisions, the district courts have jurisdiction generally in civil cases where the "matter in controversy" involves $\$ 3000$ and "arises under" the Constitution, laws, or treaties of the United States. ${ }^{36}$ To some extent the jurisdiction is exclusive, as in bankruptcy proceedings, cases under patent and copyright laws, and admiralty. ${ }^{37}$ More usually, and wherever federal authority rests upon the general grant of jurisdiction, it is concurrent with that of state courts. Within this area, however, choice of federal forum is not confined to plaintiffs. Though the complainant has elected to assert his federal right in state proceedings, the defendant may, with some exceptions specially made by Congress, remove the case into the district court. ${ }^{38}$ The measure of his right to do so, except in special cases against federal officials ${ }^{39}$ or dealt with by the Civil Rights Laws, ${ }^{40}$ is whether on the plaintiff's statement of his case he might have brought the suit originally in the federal courts. ${ }^{41}$ The revision reproduces this familiar system with small changes to be noted. There are, however, problems here that call for reconsideration.

r. It is unfortunate that, since the Act of 1875 , the statute has adopted as a test of jurisdiction in the lower courts the very language that the Constitution gives to measure the authority of Congress to vest such jurisdiction in a federal court: cases "arising under" the Constitution, laws, and treaties. The constitutional clause has properly been given broad construction. The power of the Congress to confer the federal judicial power must extend, as Marshall held, ${ }^{42}$ to every case that might involve an issue under federal law. It should extend, I think, beyond this to all cases in which Congress has authority to make the rule to govern disposition of the controversy but is content instead to let the states provide the rule so long as jurisdiction to enforce it has been vested in a federal court. Where, for example, Congress by the commerce power can declare as federal law that contracts of a given kind are valid and enforceable, ${ }^{43}$ it must be free to take the lesser step of drawing

of the jurisdiction and distinguish betwcen cases where the jurisdictional amount is necessary and those where it is not. The bill does not avoid the difficulty by breaking $\$ 24$ into separate sections, but there is no solution short of re-working all the special statutes along with Title 28 .

The revision ( $\$ 1352)$ adds to the particular grants of jurisdiction cognizance of "any action on a bond executed under any law of the United States."

${ }^{38}$ Judicial Code $\$ 24(\mathrm{I}), 28$ U. S. C. \$4I(I) (1940); H. R. 3214 , \$1331.

${ }^{37}$ H. R. 3214 abandons the device of a separate section defining the exclusive jurisdiction (Judicial Code $\$ 256,28$ U. S. C. $\$ 37 \mathrm{x}(1940)$ ) in favor of a separate statement in each instance where the grant of jurisdiction is so intended. See $\$ \$ 1333$ (admiralty), 1334 (bankruptcy), 1338 (patent and copyright), 1351 (consuls and vice-consuls as defendants), 1355 (fine, penalty, or forfeiturc), 1356 (seizurcs). The qualification of exclusiveness in admiralty, "saving to suitors in all cases the right of a common-law remedy where the common law is competent to give it" (Judicial Code, $\$_{24}(3), 28$ U. S. C. $\$_{41}(3)$ (1940)), is changed to "any other remedy to which he is otherwise entitled." For an indication of the problems in this reservation, which are unaffected by the change, see Comment, The Tangled Seine: $A$ Survey of Mar:time Personal Injury Cases, 57 YALE L. J. 243 (1947).

${ }^{38}$ Judicial Code $\$ 28,28$ U. S. C. \$7I (I940), H. R. 3214, \$I 44 I.

${ }^{30}$ Sce notes 18 and 19 stpra.

${ }^{10}$ Judicial Code $\$ 31,28$ U. S. C. $\$ 74$ (1940); H. R. $3214, \$ 1443$.

11 See, e.g., Tennessee v. Union and Planters' Bank, 152 U. S. 454 (1894).

" Osborn v. Bank of the United States, 9 Wheat. 738 (U. S. $\times 824$ ).

${ }^{13}$ See Forrester, The Jurisdiction of Federal Courts in' Labor Disputes, this symposium. 
suits upon such contracts to the district courts without displacement of the states as sources of the operative, substantive law. A grant of jurisdiction is, in short, one mode by which the Congress may assert its regulatory powers. A case is one "arising under" federal law within the sense of Article III whenever it is comprehended in a valid grant of jurisdiction as well as when its disposition must be governed by the national law.

Needless to say, Congress has not meant to grant the district courts a general jurisdiction in every case involving the jurisdictional amount in which it could confer judicial power under any of its sources of authority. That would have brought to federal adjudication all cases in the western states involving devolution of the public lands. ${ }^{44}$ There is hardly any limit to the cases it would draw today. The courts have been obliged, therefore, to draw a line between the power and the purpose of the Congress, even though their verbal measure is the same. Though the decisions are not free from vacillation, ${ }^{45}$ their essential purpose is to hold the meaning of the statute limited to cases where the plaintiff's cause of action, the rule of substance under which he claims the right to have a remedy, is the product of the federal law. ${ }^{46}$ This seems quite plainly the correct solution and one that would be happily adopted by the statute. The general clause should not be cast in constitutional language. Its scope should be expressly limited to cases where the plaintiff's claim for relief is founded on the Constitution, laws, or treaties. This change would have the added virtue of dismissing the recurrent thought that jurisdiction should not hold, though the asserted right is federal, if the case does not involve construction of the law but only finding of the facts to which the law must be applied. ${ }^{47}$ The federal courts do not sit to give material for law review articles. Their business is the vindication of the rights conferred by federal law.

2. I have suggested that there should be no amount requirement in actions against federal officers. I submit, beyond this, that the amount in controversy has no place in judging the propriety of the original jurisdiction in any case involving rights asserted under federal law. This is not, of course, to say that federal claims may not receive sufficient vindication in the state tribunals, subject to review when it is granted by the Supreme Court. But whether there should be an initial federal forum turns on the calculus of risks and benefits to which $I$ have alluded previously. The relevant considerations are such factors as the danger of hostility within the states to the particular federal affirmation, the need and value of a fairly specialized tribunal, the hardship to a party if his adversary can draw the litigation to what is often a remoter forum than the state court, the defects in state remedial systems

\footnotetext{
ts See, e.g., Shoshone Mining Co. v. Rutter, 177 U. S. 505 (1900).

${ }^{4 t}$ See Chadbourn and Levin, Original Jurisdiction of Federal Questions, go U. of PA. L. Rev. 639 (1942); Forrester, stipra note 43 .

to Sce, e.g., Gully v. First Nat. Bank, 299 U. S. I09 (I936); Puerto Rico v. Russell \& Co., 288 U. S. 476 (1933). Cases where state law incorporates federal standards by reference present a close question. See Smith v. Kansas City Title Co., 255 U. S. I80 (I921); cf. Moore v. Chesapeake \& Ohio Ry., 291 U. S. 205 (1934).

${ }^{47}$ Chadbourn and Levin, szspra note $45 ;$ Note, 40 ILL. L. Rev. 387 (1947).
} 
that may impair the vindication of the federal right. Amount has far too little bearing on these factors to employ it anywhere within this area as a decisive test. ${ }^{4 B}$ So Congress has conceived in dispensing with the standard in many, if not most, cases arising under federal statutes. There is far less reason for its maintenance when rights are asserted under treaty or the Constitution. Yet these are the very cases where, apart from actions founded on the Civil Rights Laws, the general clause provides the only basis for the jurisdiction and the amount requirement holds.

That the elimination of amount would work no inundation of the district courts is plain enough from the statistics. Most of the cases where the jurisdiction rests on federal question and the national government is not party to the action arise under statutes which already have dispensed with the requirement, as Table $\mathrm{I}^{40}$ shows.

\section{TABLE I}

\section{Civil Cases Commenced in the United States District Courts During} the Fiscal Year 1947 Where Federal Question Was Basis of Jurisdiction

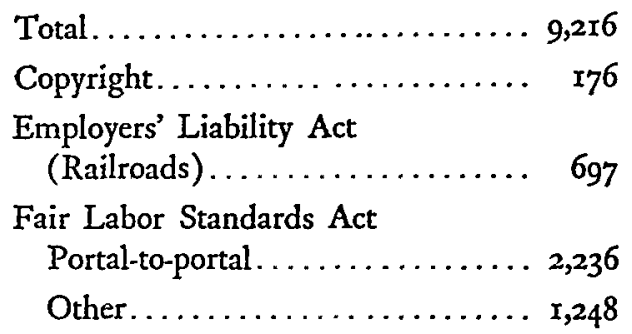

Habeas corpus.............. ' 485

Jones Act.................. 1,607

Miller Act (U. S. sub-contractor $) \ldots \ldots \ldots \ldots \ldots \ldots, 66$

Patent.................. 372
Bankruptcy (other than proceedings proper $) \ldots \ldots \ldots \ldots$ III

Civil Rights Act............. 50

Constitutionality of state statutes................. 39

Freight rates (I. C. C.)........ $\quad \times 88$

National bank receivers......... 3

Price control (O.P.A. private)..... I, 1,095

Perishable Commodities Act...... 33

Railway Labor Act............. 34

Trade-mark............... $\quad x 55$

Selective service; re-employment.... 425

Securities legislation........... 29

It is quite inconceivable that in fields now governed by the general grant of jurisdiction a flood of litigation involving less than the required amount waits impatiently at federal doors. But if reduction should be necessary in the number of federal cases, it should be accomplished by a standard more relevant than the amount in controversy to the desirability of initial federal adjudication. A survey of the federal statutory actions would speedily show those which can most prudently be relegated to enforcement in the state courts.

*8 For the close distinctions often made in calculation of amount, see, e.g., Healy v. Ratta, 292 U. S. 263 (r934); Note, 34 Coz. L. REv. 31 I (I934).

* Based on Annual Report of the DiRector of the Administrative Office of the United States Counts (1947), Table C 2, supplemented by information provided by Mr. Leland L. Tolman of the staff of the Office. 
3. Of all the litigation in which federal rights are asserted, the states have largest interest in cases where the claim is that state action-legislative or administrativeviolates the federal Constitution or conflicts with national law. The tension that such cases formerly engendered ${ }^{50}$ is largely reduced today by changes both in constitutional doctrine and in the principles that govern exercise of the original jurisdiction. The time is ripe, therefore, to frame a stable settlement. Its terms have been foreshadowed by developments in legislation and decision during recent years.

It will be helpful to recall the position when the controversy was at its height. A substantial claim of federal invalidity in action by state officials threatening "irreparable injury" gave basis for a suit for an injunction, arising under the Constitution. The jurisdiction attaching on that ground extended to "all the questions in the case." "11 Decision might be placed, therefore, on state law, such as interpretation of the statute or even a finding of its invalidity under the state constitution. Indeed, to grant relief upon state grounds was deemed to be the preferable resolution, since it dispensed with an interpretation of the federal constitution. ${ }^{52}$ In this state of jurisdictional doctrine, improvident injunctions issued on both state and federal grounds. Objection that such suits were in effect against the state and barred by the Eleventh Amendment was rejected, ${ }^{53}$ as was also the companion point that state action violating the Fourteenth Amendment-the jurisdictional averment-could not be premised upon conduct claimed to be unauthorized by state law. ${ }^{\text {.4 }}$

Congress addressed itself to the problem in several stages. It struck early at the possible improvidence of single district judges by requiring three judges when the suit demanded a preliminary injunction restraining upon constitutional grounds the enforcement of state statutes or administrative orders; and it provided in such cases a direct appeal to the Supreme Court. It also stayed the hand of federal equity if

${ }^{{ }^{\circ}}$ Sec, e.g., Frankfurter, Distribution of Iudicial Power Between United States and State Courts, 13 Cons. L. Q. 499, 519 (1928); Lilienthal, The Federal Courts and State Regulation of Public Utilities, 43 Harv. L. Rev. 379 (I930); Lockwood, Maw, and Rosenberry, The Use of the Federal Injunction in Constitutional Litigation, 43 Harv. L. Rev. 426 (1930); Warren, Federal and State Court Interference, 43 Harv. L. REv. 345 (i930).

${ }_{52}$ Siler v. Louisville \& Nashville R. R., 23r U. S. I75, r9r (r909).

${ }^{50}$ Ibid.; Greene v. Louisville \& Interurban R. R., 244 U. S. 499 (1917); Cincinnati v. Vester, 281 U. S. 439 (I930).

Ex parte Young, 209 U. S. 123 (I908).

"See Home Telephone \& Telegraph Co. v. Los Angeles, 227 U. S. 278 (1913); Mosher v. City of Phoenix, 287 U. S. 29 (1932); Isseks, Purisdiction of the Lower Federal Courts to Enjoin Unazuthorized Action of State Officials, 40 Harv. L. Rev. 969 (1927); Note, 31 Col. L. Rev. 669 (I93I).

The doctrine that official conduct cannot constitute action by a state within the limitations of the Fourteenth Amendment when such conduct is forbidden by the state's law (see Holmes, J., dissenting in Raymond v. Chicago Traction Co., 207 U. S. 20,4I (I907)), would have served to route these civil cases through the state courts. See Iowa-Des Moines National Bank v. Bennett, 284 U. S. 239 (r93I); c. Barney v. New York, 193 U. S. 430 (1904). But it would also have cast doubt upon the power of Congress to prescribe criminal sanctions to safeguard rights protected by the Amendment against their irrevocable destruction by the action of state officials (cf. Screws v. United States, 325 U. S. 91, 147148 (1945)) in contravention of the purpose of the enforcement clause (cf. Ex parte Virginia, roo U. S. $339,347(x 88))$. 
before the final hearing the state instituted suit for the enforcement of the statute or the order in its own courts and suspended its effectiveness until the final judgment. $^{55}$ The next steps came more than two decades later. The Johnson Act in $1934^{56}$ forbade injunctions restraining compliance with or the enforcement of administrative orders affecting "rates chargeable by a public utility" when (I) the basis of jurisdiction was diversity of citizenship or the constitutional invalidity of the order; (2) the order was made after reasonable notice and hearing and did not interfere with interstate commerce; and (3) "a plain, speedy and efficient remedy" in law or equity might be had in the state courts. A less qualified enactmentor in 1937 barred federal suits to enjoin "the assessment, levy, or collection of any tax imposed by or pursuant to the laws of any State" upon the same condition, that a "plain, speedy and efficient" remedy was available within the state. These statutory developments are, of course, embodied in the pending bill. ${ }^{58}$ The only change in substance is extension of the three-judge court requirement to suits for injunction in which the plaintiff does not ask preliminary relief. ${ }^{\text {G9 }}$

The courts have moved, however, well beyond the statutes. Initial decisions, addressed to the danger in such cases that relief might be erroneously granted on state grounds, employed the device of retaining jurisdiction to permit correction of the judgment if the state should subsequently hold the ground untenable. ${ }^{60}$ In that event, the federal court would be obliged to reach the federal question; and the plaintiff would retain his judgment if his federal claim should be sustained. But federal decision on doubtful state grounds was no more attractive an alternative than the unnecessary adjudication of doubtful constitutional questions-unnecessary in the sense that the determination might be avoided or much simplified if state questions could be first decided by the authoritative judgment of state courts. Neither possibility could be viewed with satisfaction by judges sensitive to the unwisdom of unnecessary federal intrusion in state matters and aware that any federal claims surviving an examination of the issues by the state tribunals could be vindicated by the Supreme Court.

The result, of course, was the prevailing doctrine of equitable abstention: when the plaintiff seeks a declaration that state action violates the federal Constitution, and the case involves preliminary or alternative state questions of some difficulty (as where interpretation of the statute is in doubt), and there is, finally, no bar to an effective remedy in state courts, the proper course is to remit the suitor to those courts. ${ }^{61}$ To be sure, the federal court will normally retain its jurisdiction of the

\footnotetext{
${ }^{E \approx}$ Judicial Code $\$ 266,28$ U. S. C. $\$ 380$ (1940); see Pogue, State Determination of State Latw and the Judicial Code, 4I Harv. L.' Rev. 623 (1928).

Eo 48 StAT. 775 (1934), 28 U. S. C. $\$ 4$ I (I) (I940).

tr 50 STAT. 738 (1937), 28 U. S. C. $\$ 41(\mathrm{I})$ (1940).

${ }^{28}$ H. R. $3214, \S \S 134 \mathrm{I}, 1342,228 \mathrm{I}, 2284$. ${ }^{\circ} \mathrm{Id} . \$ 228 \mathrm{I}$.

${ }^{00}$ Gleńn v. Field Packing Co., 290 U. S. 177 (1933); Wald Transfer \& Storage Co. v. Smith, 290 U. S. 602 (1933), Lee'v. Bickell, 292 U. S. $4^{15}$ (1934).

${ }^{\circ}$ See Railroàd Commission v. Pullman Co., 312 U. S. 496 (194r); Chicago v. Fieldcrest Dairics, 3 r6 U. S. 168 (19492); Great Lakes Dredge \& Dock Co. v. Huffman, 319 U. S. 293 (1943); Spector
} 
action, but this is hardly matter of significance. The plaintiff in the state proceeding will present his claims in full, both state and federal; if he fails within the state, his recourse on the federal issue will not be to return to the original federal jurisdiction but rather to obtain review in the Supreme Court. This modus operandi is now firmly based in the decisions. ${ }^{62}$

The development described should be extended by the statute to deny original jurisdiction in all cases that present a claim of federal invalidity in state legislative or administrative action where, in the language of the present statutes, a "plain, speedy and efficient remedy" is available in the state courts. There is no reason to exempt from application of this principle the small residuum of cases to which present limitations may be held inapplicable, as where state law is not conceived to be uncertain or the constitutional issue is presented in an action that would formerly have been at law. The crucial point is one of general validity: it is that application of the federal authority to invalidate the action of a state is best accomplished when the issue finds its way to the Supreme Court after it has had examination in the state courts. This is, moreover, the kind of situation where review by the Supreme Court is neither doubtful nor unduly burdensome if there is substantial basis for the claim of invalidity; appeal will often lie of right, ${ }^{63}$ and when it does not, certiorari will but rarely be denied; adverse findings on the facts will not, unless supported, defeat reversal for denial of a federal right. ${ }^{64}$ Further, this is typically the kind of case that would not be determined through the avenue of the original jurisdiction without ultimately reaching the Supreme Court. Accordingly, the only basis for retention of original jurisdiction is that state remedies may be too uncertain, slow, or ineffective-matters that call for judgment in particular situations; where that is found to be the case, original jurisdiction would and ought to be preserved. ${ }^{65}$

Motor Service, Inc. v. McLaughlin, 323 U. S. ro1 (1944); Alabama State Federation of Labor v. McAdory, 325 U. S. 450 (1945); A. F. of L. v. Watson, 327 U. S. 582 (1946). But in Railroad Commission v. Rowan \& Nichols Oil .Co., 310 U. S. 573 (1940), having first considered the constitutional claim, with denial of relief, the Court felt obliged on rehearing (3II U. S. 614) to pass on the state ground urged, holding it to be insufficient as well.

The values embodied in the doctrine are, of course, also reflected in part in the criteria that otherwise determine whether there is a basis for equitable relief. See, e.g., Cavanaugh v. Looney, 248 U. S. 453 (I919); Matthews v. Rodgers, 284 U. S. 52 I (1932); Spielman Motor Sales Co. v. Dodge, 295 U. S. 89 (1935); Beal v. Missouri Pacific R. R. Corp., 312 U. S. 45 (194I).

${ }^{2}$ The differences that have arisen lie primarily in situations where diversity affords an independent basis for the jurisdiction and this is urged to lend compulsion to decision on state grounds. See Burford v. Sun Oil Co., 319 U. S. 315 (1943); cf. Meredith v. Winter Haven, 320 U. S. 228 (I943); Hawks نे. Hamill, 288 U. S. 52, 60-6I (1933). But see also Public Utilities Commission v. United Fuel Gas Co., 317 U. S. 456 (1943).

I urge hereafter that if diversity is to be retained, there should at least be no compulsion to adjudicate upon uncertain state grounds. Compare the technique employed in Thompson v. Magnolia Petroleum Co., 309 U. S. 478 (1940) to obtain a state determination of a difficult state question arising in a bankruptcy proceeding.

${ }^{3}$ See, e.g., Dahrike-Walker Milling Co. v. Bondurant, 257 U. S. 282 (I92I).

os See è.g., Fiske v. Kansas, 274 U. S. 380 (1927).

${ }^{o t}$ See, e.g., Hillsborough v. Cromwell, 326 U. S. 620 (1946). Injunctions against proceedings in state courts present an analogous problem. "The bill $(\$ 2283)$ would restore the so-called "relitigation" exception to the probibition of Judicial Code $\$ 265,28$ U. S. C. $\$ 379$, existence of which was denied in 
These observations call for qualification in one instance: the rights of action specially conferred by Congress in the Civil Rights Laws. ${ }^{66}$ There Congress has declared the historic judgment that within this precious area, often calling for a trial by jury, there is to be no slightest risk of nullification by state process. The danger is unhappily not past. It would be moving in the wrong direction to reduce the jurisdiction in this field-not because the interest of the state is smaller in such cases, but because its interest is outweighed by other factors of the highest national concern. ${ }^{67}$ Needless to say, to formulate the scope of the exception is no drafting problem; its measure is the rights of action given by the Civil Rights Laws. ${ }^{68}$

4. The doctrine that would bar original jurisdiction to invalidate state action when there is a "plain, speedy and efficient" remedy in state courts presupposes that the party who objects to jurisdiction will establish that the remedy obtains. ${ }^{60}$ There is, however, one important case that should be governed by this principle where under present law and under the revision the burden is imposed the other way. This is the case of federal habeas corpus in so far as it is used to challenge upon federal grounds the validity of detention under criminal conviction in state courts.

The issue has, of course, been brought to prominence in recent years by decisions of the Supreme Court expanding the procedural requirements of due process in state criminal proceedings and holding that, to some extent at least, when such requirements have been denied a judgment cannot stand even on collateral attack. Since federal habeas corpus runs in any case of imprisonment "in violation of the Constitution or of a law or treaty of the United States,"70 the writ has been sought increasingly to challenge state convictions on such grounds. The Supreme Court has, however, held that principles of comity preclude this resort to original jurisdiction unless state remedies have been exhausted by the petitioner. Its doctrine is that a district court should entertain the petition where "resort to state court remedies has failed to afford a full and fair adjudication of the federal contention raised, either because the state affords no remedy ... or because in the particular case the remedy afforded by state law proves in practice unavailable or seriously inadequate."71 The application of the doctrine has produced much obvious procrastina-

Toucey v. New York Life Insuranoe Co., 314 U. S. 118 (1941), by sanctioning restraint by a fecleral court "where necessary in aid of its jurisdiction, or to protect or effectuate its judgments." Under the rule of the Toucey case the claim of res adjudicata would be asserted in the state court but its erroneous denial would, of course, present a federal question. See Taylor and Willis, The Power of Federal , Courts to Enjoin Proceedings in State Courts, 42 YALE L. J. 1169 (r933); Warren, Federal and State Court Interference, 43 Harv. L. Rev. 345 (r930).

${ }^{66} 8$ U. S. C. $\$ \$ 43,47,48$ (r940); Judicial Code $\$ 24(12),(13),\left(1_{4}\right), 28$ U. S. C. $\$_{4}$ I $_{(2)}$ ), (13), (14) (1940).

ot See To Secure These Rrghts, Report of the President's Commitee on Civil Rights (1947).

"The normal requirements for equitable relief apply, however, in this area as well. See Douglas v.

City of Jeannette, 319 U. S. 157 (1943); cf. Hague v. C. I. O., 307 U. S. 496 (1939).

"See Hillsborough v. Cromwell, stpra note 65; Driscoll v. Edison Co., 307 U. S. 104 (1939); Mountain States Power Co. v. Public Service Comm'n, 299 U. S. 167 (1936).

${ }^{70}$ REv. STAT. $\$ 753,28$ U. S. C. $\$ 453$ (1940); H. R. 3214, $\$ 224$ I(c)(3).

${ }^{11}$ Ex parte Hawk, 321 U. S. 124,118 (1944). 
tion in the situation where state post-conviction remedies are shrouded in uncertainty, and countless theoretical contingencies remain to be resolved. ${ }^{72}$

The draft has properly addressed itself to this and other ${ }^{73}$ problems of the federal habeas corpus, but both its language ${ }^{74}$ and the substitute ${ }^{75}$ proposed by the Judicial Conference perpetuate the difficulty noted. It should be met by recognition that these cases do not warrant treatment different from that given others which invoke original jurisdiction to invalidate state action; the jurisdiction should be open not when it is plain that the state courts provide no remedy, but rather unless the availability of such a remedy is clear. ${ }^{76}$ The consequence, we may be certain, will be rapid clarification of state remedies; for it is obviously to state advantage to channel re-examination of convictions through its own judicial processes, subject to review by the Supreme Court.

5. Attention has been called in the discussion of state-action cases to the scope of the original jurisdiction based on federal question, in so far as it includes companion claims to remedy founded solely on state law. The doctrine was, as has been noted, that jurisdiction vesting on the basis of the federal question extended to all questions in the case. The same issue also arose in actions under federal statutes in which the plaintiff claimed relief on state as well as federal grounds. A different rule developed here-especially in patent, trade-mark, and copyright cases-limiting the scope of jurisdiction in such statutory actions to the claim raised under federal law. ${ }^{77}$

${ }^{72}$ See, e.g., Rutledge, J., concurring in Marino v. Ragen, 68 Sup. Ct. 240, 241 (U. S. 1947); Note, 15 U. of Chr. L. REv. I07, 118 (I947); Note, 22 IND. L. J. 262 (1947).

73 The order to show cause procedure sanctioned in Walker v. Johnston, 312 U. S. 275 (I94I), is expressly provided (H. R. $3214, \$ 2243$ ). A second petition after a prior determination is barred if it presents no "new grounds" (\$2244). A judicial certificate "setting forth the facts occurring at the trial" is rendered admissible in evidence (\$2245). Proof by affidavit is allowed in the discretion of the court, subject to a right to cross-examine by written interrogatories (\$2246). Federal sentencing courts are authorized to hear on motion to vacate any grounds for collateral attack and resort to such motion is made a prerequisite to habeas corpus (\$2255).

These provisions are largely based on the bills recommended by the Judicial Conference (H. $R$. 4232, 4233, 79th Cong., Ist Sess.); see Report of the Judicial Conference of Senior Circuit Judges 23-24 (1943); see also Report of the Judicial Conference, 92 L. Ed. 125, 133 (1947).

"The draft (\$2254) is plainly in error in extending the rule to all persons in custody pursuant to "authority of a State officer." Cf. In' re Neagle, I35 U. S. I (1890); In re Loney, 134 U. S. 372 (1890); Wildenhus's Case, 120 U. S. I (1887).

${ }^{2}$ Sec Report, 92 L. Ed. 125, 134 (1947): "An application for writ of habeas corpus in behalf of a person in custody pursuant to the judgment of a state court shall not be granted unless it appears that the applicant has exhausted the remedies available in the courts of the state or that there is no adequate remedy available in such courts. . An applicant shall not be deemed to have exhausted the remedies available in the courts of the state, within the meaning of this section, if he has the right under law of the state to raise the question presented by any available procedure. The phrase 'no adequate remedy' as used in this section means the absence of state corrective process or the existence of exceptional circumstances rendering such process ineffective to protect the rights of the prisoner."

The Judicial Conference also proposed a far preferable alternative to $\$ 2244$ relaxing the rigor of the finality rule proposed by the bill, while permitting denial of a petition presenting no new ground if "the judge or court is satisfied that the ends of justice will not be furthered by such inquiry."

"See Rutledge, J., concurring in Marino v. Ragen, supre note 72.

${ }_{77}^{7}$ See, e.g., Leschen Rope Co. v. Broderick, 201 U. S. I66 (1906); Stark Bros. Co. v. Stark, 255 U. S. 50 (192I); Planten v. Gedney, 224 Fed. 382 (C. C. A. $2 d$ 1915); Levering \& Garrigues Co. v. Morrin, 6r F. 2d II5 (C. C. A. 2d 1932), aff'd on other grounds, 289 U. S. ro3 (1933); see Note, 32 CoL. L. Riev. 29I, 296 (1932). 
The contrary lines of doctrine confronted the Supreme Court in Hurn v. Oursler, ${ }^{78}$ an action for infringement of a copyright accompanied by claims of unfair competition in the plagiarization of both the copyrighted document and another but uncopyrighted version of the same play. Decision held the jurisdiction not confined to the adjudication of the statutory claim but limited to state-created rights involved in the "same cause of action," a concept measured for this purpose by the element of unity provided by the copyrighted play. ${ }^{70}$ Presumably, the cause-of-action doctrine with its test of substantial identity in operative facts would now apply to any type of case. It is, however, plain that application of the principle has been a source of constant difficulty and has led to close distinctions that seem hardly to have bearing either on the general values that should govern in the administration of justice or on the special value of avoiding federal intrusion in state spheres. ${ }^{80}$

The draft deals with the issue only in so far as it involves the conjunction with alleged infringement in the patent, copyright, and trade-mark cases of a claim of unfair competition, grounded necessarily ${ }^{81}$ upon state law. It provides ${ }^{82}$ that jurisdiction shall extend to unfair competition "when joined with a substantial and related claim" under the federal statutes. The notes of the Reviser imply that he has based this formulation on the decision in Hurn v. Oursler. It is quite plain, however, that if the word "related" is accorded any portion of its normal meaning it will substantially expand the scope of jurisdiction. Many circumstances will suffice to show relation where the grievances would not be held to rest on operative facts sufficiently identical to keep the cause of action "single," within the purport of the present rule.

It would be wiser if the bill attempted a more general solution and one that would have greater relevancy to the required separation of authority within the féderal-state relationship. There is a vice in federal adjudication on state grounds inhering in the fact that federal courts are not the authorized expositors of state law; there is no mechanism by which their errors in such matters can be corrected on appeal by state courts. There is a vice also, as we have recognized by liberal rules of joinder, ${ }^{83}$ in forcing plaintiffs who have multiple bases of action to pursue their remedies in pieces and in different courts. ${ }^{84}$ It is, however, possible to find a balance

${ }^{78}{ }_{289}$ U. S. 238 (1933); see Note, 32 Col. L. Rev. 688, 699 (1932); Shulman and Jaegerman, Some Jurisdictional Limitations on Federal Procedure, 45 YALE L. J. 393 (1936).

${ }^{70}$ Cf. Armstrong Co. v. Nu-Enamel. Corp., 305 U. S. 315,.325 (1938): "Registration of 'Nu-Enamel' furnished $a^{*}$ substantial ground for federal jurisdiction. That jurisdiction should be continued to determine, on substantially the same facts, the issue of unfair competition." See also Southern. Pac. Co. v. Van Hoosear, 72 F. 2d 903 (C. C. A. 9th 1934). (interstate and intrastate rates as alternative grounds for relief).

${ }^{80}$ See, e.g., the decisions cited supra note ro; Note, 52 YALE L. J. 922 (1943).

${ }^{81}$ See Pecheur Lozenge Co. v. National Candy Co., 315 U. S. 666 (1942). That the applicable law is unaffected by whether jurisdiction rests on diversity or on the companion federal claim is ably demonstrated by Wyzanski, J., in National Fruit Product Co. v. Dwinell-Wright Co., 47 F. Supp. 499 (D. Mass. 1942). The contrary view is stated by Zlinkoff, Erie v. Tompkins: In Relation to the Law of TradeMarks and Unfair Competition, 42 CoL. L. REv. 955 (1942).

${ }^{82} \$ 1338(\mathrm{~b})$.

${ }^{83}$ Fed.. R. Crv. P., 18, 20.

.81 Needless to say, the vice is greatest when, as in patent and copyright.cases, the federal jurisdiction is exclusive with respect to the federal claim; the plaintiff cannot avoid fragmentation by resort to the 
for these evils. The balance is achieved if jurisdiction is extended generally to claims that under joinder rules may be asserted in a single action, subject to discretion in the court to dismiss without prejudice claims resting upon state law. When uncertainty obtains as to prevailing local doctrine, when that doctrine is enmeshed in clashing policies that render any legal formulation an intrinsically changing concept, the discretion would be exercised to limit federal adjudication to the federal grounds. When, on the contrary, the issue turns on principles well settled by the state, the federal courts can safely undertake the full adjudication of the case. This is the very plan adopted by the draft in dealing with removal from state courts. ${ }^{85}$ It should be given general application in measuring the scope of the original jurisdiction based on federal question. Provision might be made to toll statutes of limitation while the claim is pending in the federal court.

6. The bill retains the rule of present law that a defendant may remove a case in a state court founded on a federal "claim or right"-provided it is one "of which the district courts have original jurisdiction." plications. Though the plaintiff who puts forth the federal claim is content to seek its vindication in the state tribunals, the defendant may insist upon an initial federal forum. When, on the other hand, the plaintiff's reliance is on state law and the defendant claims a federal defense, neither party may remove ${ }^{87}$ - except, of course, the special case, to which attention has been called, of actions against federal officials. Nor is there either original jurisdiction or removal where both the initial claim and the defense rest on state law but the plaintiff contends that the defense put forth is nullified by federal law..$^{88}$

It would, it seems to me, be far more logical to shape the rule precisely in reverse, granting removal to defendants when they claim' a federal defense against the plaintiff's state-created claim and to the plaintiff when, as the issues have developed, he relies by way of replication on assertion of a federal right. The need is to

state court. Cf. Clark, J., in Musher Foundation v. Alba Trading Co., 127 F. 2d 9, II (C. C. A. $2 d$ 1942): "If the roast must be reserved exclusively for the federal bench, it is anomalous to send the gravy across the street to the state court house."

${ }^{80} \S_{144 I}(c)$ : "Whenever a separate and independent claim or cause of action, which would be" removable if sued upon alone, is joined with one or more otherwise non-removable claims or causes of action, the entire case may be removed and the district court may determine all issues therein, or, in its discretion, may remand all matters not otherwise within its original jurisdiction."

This provision is not limited to diversity cases, though apparently drafted 'with them in mind. See Reviser's notes, pp. A-r $33-134$. It has the result, novel in federal question cases generally, of conferring a broader jurisdiction on removal than when action is instituted in the district court.

${ }^{86} \$ 144$ I (a), Judicial Code $\$ 28,28$ U. S. C. $\$ 7 \mathrm{I}$ (I940). The consequence of the formulation is that the complaint must show that the action arises under federal law. Ténnessee v. Union \& Planters' Bank, I52 U. S. 454 (1894). In so far as removal has been specially forbidden by Congress (e.g.,

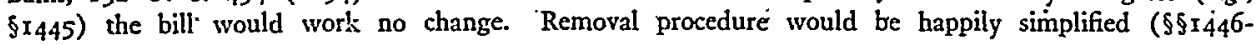
1450 ).

-87 Tennessee v. Union \& Planters' Bank, stupra note 86; Walker v. Collins, I67 U. S. 57 (I897). The plaintiff's removal, originally provided in the Act of 1875 . (Railroad Co, v. Mississippi, to2 U. S. $135(1880)$ ) was eliminated by the Acts of $188 j$ and $r 888$.

${ }_{\text {ss }}$ Louisville \& Nashville R. R. v. Möttley, 2 ir U. S. I49 (Ig08). Jurisdićtion may depend therefore on whether the equitable or the legal tradition determines what the plaintiff must allege. See, e.g., White v. Sparkill Realty Corp., 280 U. -S. 500 (1930):" 
remember that the reason for providing the initial federal forum is the fear that state courts will view the federal right ungenerously. That reason is quite plainly absent in the only situation where, apart from federal officers, removal now obtains: the case where the defendant may remove because the plaintif's case is federal..$^{80}$ If in any case the reason can be present, it is only in the situations where removal is denied.

The statute ought to be reshaped in terms of a consistent theory that permits removal by the party who puts forth the federal right, or else removal should be dropped entirely in cases where the jurisdiction is based on federal question. To drop it seems to me the better course, for reasons indicated in the discussion of the state-action cases. When the defendant claims a federal defense to an asserted right founded on state law, his assertion is, in substance, that there is pro tanto invalidity in the demanded application of that law. The same is true when federal grounds are first advanced to push aside a state defense to a state cause of action. In both these situations, therefore, the matter should be viewed in terms of principles appropriate to state-action cases. And since there is no doubt in either case of adequacy of state remedy, the statute should confine the litigation to state courts. No one would urge that criminal cases in state courts should be removable generally because a federal defense is interposed. The reason holds for civil litigation too. There is no need for the original jurisdiction when litigants rely on federal rights to furnish them a shield but not a sword.

What has been said is not intended to refer to actions against federal officers founded on official conduct. Such cases are, as has been said, of special federal interest because they constitute, in substance, suits against the national Government. The bill correctly deals with them in separate sections, providing a removal on that ground. ${ }^{90}$

IV

\section{Diversity of Citrzenship}

A substantial segment ${ }^{91}$ of the business of the district courts in cases where the

"It is not surprising therefore that the number of removals on this ground is always very small, only 87 cases in fiscal 1947. Sec annual Report of the Director of the Administrative 'Ofpicb of THE United States Courts, Table C-2 (rg47).

${ }^{10}$ See note 18 supra.

'1 The Administrative Office reports the proportion of all civil cases (other than bankruptcy) based on diversity as follows:

\begin{tabular}{|c|c|c|c|c|c|c|c|c|}
\hline Total civil cases & $\begin{array}{l}\times 940 \\
26756\end{array}$ & $\begin{array}{l}194 I \\
28909\end{array}$ & $\begin{array}{c}1942 \\
29592\end{array}$ & $\begin{array}{c}1943 \\
28 \times 66\end{array}$ & $\begin{array}{c}1944 \\
29742\end{array}$ & $\begin{array}{r}1945 \\
52144\end{array}$ & $\begin{array}{r}1946 \\
57512\end{array}$ & $\begin{array}{c}1947 \\
48809\end{array}$ \\
\hline $\begin{array}{l}\text { Total diversity of } \\
\text { citizenship cases }\end{array}$ & 7252 & 7286 & 7135 & 5468 & 5233 & 5268 & 6242 & 86 \\
\hline $\begin{array}{l}\text { ercent of diversity } \\
\text { of citizenship cases }\end{array}$ & 25.2 & 27.1 & $24 . x$ & 19.4 & 17.6 & 10.1 & 20.0 & 17.8 \\
\hline
\end{tabular}

The war-time years reflect both the decline in private litigation and the great volume of OPA cases. The proportion of diversity cases is, of course, much higher if government litigation is climinated from the total of civil cases. See, e.g., the table in Part I, supra. Rough estimates of the Administrative Office showed 29 per cent of all trial days devoted to diversity cases in fiscal 1942, 19 per cent in fiscal 
Federal Government is not a party derives from the jurisdiction in controversies between citizens of different states. This and the companion case where the authority is based on citizenship and alienage pose the deepest issue of the uses of the federal courts. In these instances the jurisdiction is employed not to vindicate rights grounded in the national authority but solely to administer state law. Withdrawal of these cases from the state judicial processes involves, therefore, a patent violation of the principle so strongly urged originally to justify the federal judicial power: that judicial authority must be coextensive with the legislative. ${ }^{92}$ The state judicial power is less extensive than its legislative when a portion of the task of state administration is assumed by federal courts whose judgments are not subject to a state review. The problem is, therefore, whether this exceptional judicial undertaking rests on some present, valid, federal purpose. If not, it is a function that should plainly be surrendered to the states. ${ }^{93}$

The nature of the cases in which diversity brings federal adjudication is suggested with some clarity in Table 2, drawn from the reports of the Director of the Administrative Office. ${ }^{94}$

It would be difficult to think of litigation posing problems more intrinsically local than pictured by this data.

Those who defend the jurisdiction point, of course, to the original fear of prejudice against the litigant from out of state ${ }^{95}$ and argue that the danger is not gone today. ${ }^{96}$ I share the view that this provides an insufficient answer, that when this sentiment exists and works unfairness, the protection must be found, as in the

1946 , and 24 per cent of days not devoted to the exceptional war-time work in OPA and Selective Service cases. For earlier data see Charles E. Clark, Diversity of Citizenship Jurisdiction of the Federal Cotrts, 19 A. B. A. J. 499 (1933); Asferichn Law Instrtute, A Study of the Business of the Federsi Courts, Pt. II, 47, 99-100, 102, 205 (I934).

${ }^{22} \mathrm{Cf}$. The Federalist No. LXXX (Hamilton): "If there are such things as political axioms, the propriety of the judicial power of a government being coextensive with its legislative, may be ranked among the number." See also I ANwals of CoNGress 843 (Madison) (1789).

" For Senator Norris' reports from the Senate Judiciary Committee favorable to abolition of diversity jurisdiction, sec SeN. Rep. No. 530, 72d Cong., Ist Sess. (1932); SEN. Rep. No. 691, 7rst Cong., 2d Sess. (1930). See also Frankfurter, Distribution of Judicial Power Between United States and State Courts, 13 Cors. L. Q. 499, 520 et seq. (1928); Yntema and Jaffin, Preliminary Analysis of Concurrent Jurisdiction, 79 U. of PA. L. Rev. 869 (I93I); Frankfurter, A Note on Diversity JurisdictionIn Reply to Professor Yntema, 79 U. oF PA. L. Rev. I097 (I93I); Limiting Jurisdiction of Federal Courts-Comment by Members of Chicago University Law Faculty, 31 Mich. L. Rev. 59 (1932); Parker, The Federal Jurisdiction and Recent Attacks Upon It, I8 A. B. A. J. 433, 437-439 (1932); Howland, Shall Federal Jurisdiction of Controversies Between Citizens of Different States be Preserved? 18 A. B. A. J. 499 (1932); Yntema, The Jurisdiction of Federal Courts in Controversies Betsueen Citizens of Different States, 19 A. B. A. J. 71, 149, 265 (1933); Clark, stpra note 91; Ball, Revision of Federal Diversity, lurisdition, 28 ILL. L. REv. 356 (1933); McGovney, A Supreme Court, Fiction: III, 56 HaRv. L. REv. 1225 (1943).

" See Annual Report of the Director of the Adaminstrative Office of the United States Courts, Table 7 (1942); id. (1944) Table 6; id. (1946) Table C 2, p. 89; id. (1947) Table C 2.

${ }^{\circ 5}$ See Warren, New Light on the History of the Federal Judiciary Act of 1789, 37 Harv. L. REv. 49, 83 (1923); Friendly, The Historic Basis of Diversity Jurisdlation, 41 Harv. L. Rev. 483,487 (1928); Frank, Historical Bases of the Federal Judicial System, this symposium.

"Sec, e.g., Parker, supra note 93. 
TABLE 2

Diversity Cases in District Courts by Nature of Suit, I941-r947

\begin{tabular}{|c|c|c|c|c|c|c|c|}
\hline & 1941 & 1942 & 1943 & 1944 & 1945 & $19 \div 6$ & 1947 \\
\hline Total diversity cases . . . . . . . . . . . . . & 7286 & 7135 & 5468 & 5233 & 5268 & $62+2$ & 8602 \\
\hline 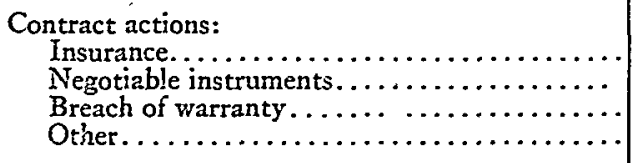 & $\begin{array}{r}1163 \\
127 \\
256 \\
1139\end{array}$ & $\begin{array}{r}1156 \\
98 \\
172 \\
1209\end{array}$ & $\begin{array}{r}953 \\
54 \\
56 \\
1048\end{array}$ & $\begin{array}{r}1053 \\
55 \\
62 \\
1012\end{array}$ & $\begin{array}{r}1099 \\
47 \\
26 \\
969\end{array}$ & $\begin{array}{r}1269 \\
39 \\
47 \\
1107\end{array}$ & $\begin{array}{r}1+54 \\
72 \\
77 \\
1654\end{array}$ \\
\hline $\begin{array}{l}\text { Real property actions: } \\
\quad \text { Foreclosure. } \ldots \ldots \ldots \ldots \ldots \ldots \ldots \ldots \ldots \\
\quad \text { Other (except torts) } \ldots \ldots \ldots \ldots \ldots \ldots\end{array}$ & $\begin{array}{c}81 \\
418^{97}\end{array}$ & $\begin{array}{c}60 \\
\pm 11^{97}\end{array}$ & $\begin{array}{r}30 \\
213\end{array}$ & $\begin{array}{r}17 \\
160\end{array}$ & $\begin{array}{r}16 \\
216\end{array}$ & $\begin{array}{r}16 \\
230\end{array}$ & $\begin{array}{r}14 \\
292\end{array}$ \\
\hline 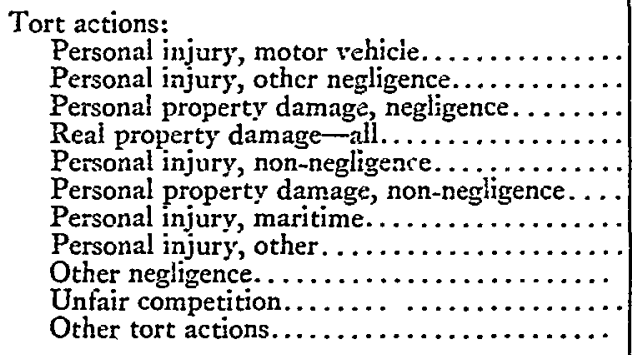 & $\begin{array}{r}1829 \\
\ldots \\
\ldots \\
\ldots \\
\ldots \\
\ldots \\
1159 \\
140 \\
83 \\
365\end{array}$ & $\begin{array}{r}2010 \\
\ldots \ldots \\
\ldots \ldots \\
\ldots \ldots \\
\ldots \\
75 \\
10,42 \\
131 \\
41 \\
333\end{array}$ & $\begin{array}{r}1222 \\
1214 \\
64 \\
51 \\
161 \\
171 \\
\ldots \ldots \\
\ldots \\
\ldots \\
\ldots \\
\ldots\end{array}$ & $\begin{array}{r}1034 \\
1220 \\
38 \\
100 \\
183 \\
137 \\
\ldots \ldots \\
\ldots \ldots \\
\ldots \ldots \\
\ldots \ldots\end{array}$ & $\begin{array}{r}10: 40 \\
1311 \\
56 \\
83 \\
151 \\
122 \\
\ldots \ldots \\
\ldots \ldots \\
\ldots \ldots \\
\ldots \ldots\end{array}$ & $\begin{array}{r}1368 \\
1504 \\
65 \\
162 \\
161 \\
154 \\
\ldots \ldots \\
\ldots \ldots \\
\ldots \ldots \\
\ldots \ldots\end{array}$ & $\begin{array}{r}2116 \\
2164 \\
107 \\
141 \\
229 \\
203 \\
\ldots \ldots \\
\ldots \ldots \\
\ldots \ldots \\
\ldots \ldots\end{array}$ \\
\hline All other........... & 471 & 347 & 231 & i6: & 132 & 120 & 169 \\
\hline
\end{tabular}

case of other prejudices threatening administration of state justice, in state appellate processes-including, when due process, is denied, review by the Supreme Court. ${ }^{.8}$ It is, indeed, a rather startling thought that this least troublesome of all the prejudices should be the basis of a special federal forum which none of the hostilities that flow from faction, interest, race, or creed is deemed sufficient to provide. But even if the prejudice hypothesis is thought to warrant federal intervention, it is quite plain that the diversity jurisdiction is not defined in terms that are responsive to the theory.

The jurisdiction holds though neither party is a resident of the state in which the action has been brought. 99 It holds upon removal based on "separable controversy," though when the case is taken as a whole citizens of the same state are on both sides. $^{100}$ It is not limited to cases tried by jury. A bona fide foreign domicile will

${ }^{97}$ The total given for these years includes torts.

${ }^{28}$ See, e.g., Judge Denman's testimony on behalf of twenty-four circuit and district judges of the Ninth Circuit in support of S. 466,79 th Cong., Ist Sess., to abolish diversity jurisdiction except for removal by a non-resident defendant in a state court action upon a showing that "from prejudice or local influence he will not be able to obtain justice in such State court." Hearing Before the Senate Judiciary Committee, October 8, 1945. And see note 93 supra.

${ }^{80}$ In this respect the modern statute is broader than the Act of 1789 , which limited the jurisdiction to the situation where "the suit is between a citizen of the State where the suit is brought, and a citizen of another State." See Warren, supra note 96 , at 79 .

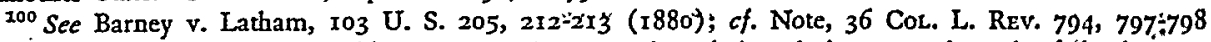
(1936): "Since under the 'separable controversy' statute the whole suit is removed to the federal court, the inquiry as to whether the citizen against whom relief is prayed is a necessary party to the adjudication of the controversy urged to be separable is really an academic one based upon the unreal premise that in case of removal some of the original parties to the suit would not be before the federal court." 
give an individual foreign citizenship ${ }^{101}$ whatever is in fact his contact with the state of litigation or his standing at its bar. Jurisdiction once attaching will survive though the parties have become united in their citizenship. ${ }^{102} \mathrm{~A}$ few selected litigants with diverse citizenship will suffice for the determination of class suits ${ }^{103}$ in which the major interests may be centered in one state. By the only outright legal fiction of importance that survives in modern jurisprudence, all the stockholders of any corporation are conclusively presumed to be citizens of the state of incorporation, with the result that a diversity exists when the corporation litigates with a resident of any other state, including, by the same token, a corporation organized under its laws. ${ }^{104}$ If North Carolina residents operate a North Carolina business through a corporation organized in Delaware, all their controversies with their fellow North Carolinians may be litigated in the federal forum, provided only that they involve the jurisdictional amount.

The corporate anomaly is, of course, judicially created ${ }^{105}$ and may yet yield to an attack in the Supreme Court. ${ }^{106}$ Statistical analysis suggests that correction of this ancient and "malignant"107 error would reduce by 70 per cent the recent volume of diversity cases in the federal courts. ${ }^{108}$

Enough has been said to indicate the nature of the issues that demand consideration in this area. They have been given scant attention in the bill. It will increase the federal litigation on negotiable instruments by eliminating the provision ${ }^{109}$ requiring diversity between the plantiff's assignor and the defendant, though no assignment that is merely colorable will suffice to create jurisdiction. ${ }^{110}$ Pursuant to the policy of the amendment passed in $1940,{ }^{111}$ residents of the District of Columbia and the territories will be treated as citizens of states-an extension that involves

${ }^{201}$ See Morris v. Gilmer, 129 U.. S. 315, 328 (1889).

${ }^{102}$ Mullen v. Torrance, 9 Wheat. 537 (U. S. 1824 ). For discussion of the jurisdictional significance of changes in citizenship or parties after action brought, see Schlesinger and Strasburgher, Divestment of Federal Jurisdiction, 39 CoL. L. Rev. 595 (1939).

${ }^{103}$ Supreme Tribe of Ben-Hur v. Cauble, 255 U. S. 356 (192x). The requirement of complete diversity (Strawbridge v. Curtiss, 3 Cranch 267 (U. S. 1806)) is further circumvented by permitting intervention. See Stewart v. Dunham, iI5 U. S. 6I (i885); see 2 Moore's Federal Practice' 24I3 et seq. (1938). Rule 19 (b) of the Federal Rules of Civil Procedure recognizes as a reason for nonjoinder that an absent party's presence would defeat jurisdiction, a curious, partial repudiation of the policy of the jurisdictional rule.

104 For the fullest account of this development, see McGovney, A Stipreme Court Fiction, 56 Harv.

L. REv. 853, rogo, 1225 (1943).

${ }^{105}$ See, e.g., Marshall v. Baltimore \& Ohio R. R., 16 How. 314 (U. S. 1854).

100 The advocate who would launch the attack will find his arsenal in McGovney, supra note ro4. For discussion of the counter-argument of Congressional acquiescence, see McGovney, supra note ro4, at $1118-1124$.

207 The word is Charles Warren's, supra note 96 , at 90 :

${ }^{108}$ Sec Appendix, infra.

${ }^{200}$ Judicial Code $\S_{4}(x), 28$ U. S. C. $\$_{4} I(I)$ (1940): "No district court shall have cognizance of any suit (except upon foreign bills of exchange) to recover upon any promissory note or other chose in action in favor of any assignee, or of any subsequent holder if such instrument be payable to bearer and be not made by any corporation, unless such suit might have been prosecuted ... if no assignment had been made."

${ }^{110} \mathrm{H} . \mathrm{R} .3214, \S 1359$.

${ }^{212}$ Act of April 20, 1940, 54 StAт. I43. . 
a major constitutional issue that should soon be resolved by the Supreme Court. ${ }^{112}$ A removal would continue to be sanctioned when only a portion of a case involves complete diversity, but there is improvement in the formulation of the rule that governs in such cases and substantial gain in vesting in the district court discretion to remand the separable issues as to which diversity is incomplete. ${ }^{113}$ In so far as venue rules now limit invocation of original jurisdiction, though not removal, ${ }^{114}$ to cases where the plaintiff can effect service of process in the state of his or the defendant's residence, ${ }^{115}$ a major change lurks in the draft. When venue is laid in a wrong "division or district" it is provided that the court "shall" transfer the case "to any district or division in which it could have been brought."110 If this means what it says, a plaintiff need only file in any district where the process can be served and sit back to await the transfer of the cause. The result, if it is thought to be desirable, ${ }^{117}$ would be achieved more satisfactorily by permitting process to run to any district but adhering to the rule that improper venue is cause for dismissal unless the point is waived.118

These are, however, small details in contrast to the program that is called for in connection with diversity. What is needed is a total reconsideration of the jurisdiction, guided by the principle that federal judicial energy should be preserved for vindication of those interests which, because the Congress has considered them of national importance, have become the subject of the federal substantive law. Within that sphere and that alone, federal courts can function as creative agents, the authorized interpreters of Constitution, treaty, and statute, the acknowledged sources of that subordinate and interstitial legislation which must come in any system from the courts. In many ways the worst part of diversity jurisdiction is that it debases the judicial process, reducing federal judges to what Judge Frank has

${ }^{122}$ H. R. 3214 , $\$ 1359(3)(b)$. See Central States Cooperatives, Inc. v. Watson Bros. Transportation

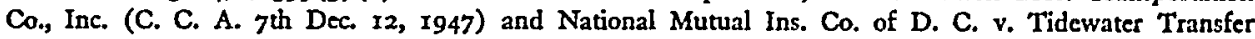
Co., Inc. (C. C. A. $4^{\text {th }}$ Dec. 31 , 1947), both holding against validity of the 1940 amendment by divided court. The ultimate question is whether the provision can be viewed as a regulation of the District of Columbia when it is addressed to district courts sitting in the states and limits the right of a state citizen to litigate in its courts.

${ }^{113}$ H. R. $3214 \$ 144 \mathrm{I}(\mathrm{c})$, supra note 85 . The divorcement of diversity jurisdiction from policy is well indicated by asking what factors the court should weigh in exercising its discretion to adjudicate or remand, an answer that is fairly plain when jurisdiction rests on federal question.

${ }^{124}$ Lee v. Chesapeake \& Ohio Ry., 260 U. S. 653 (1923).

${ }^{115}$ Judicial Code $\$ 5 x, 28$ U. S. C. $\$ I I 2$ (1940); Fed. R. Civ. P., $4(f)$; see Camp v. Gress, 250 U. S. 308 ( $19 \mathrm{rg})$.

220 H. R. 3214, $\$ 1406$ (a). Sub-section (b) provides: "Nothing in this chapter shall impair the jurisdiction of a district court of any matter involving a party who does not interpose timely and sufficient objection to the venue." But of. \$1693.

These provisions also apply to cases where diversity is not a ground of jurisdiction and the venuo is generally only the district of the defendant's residence $(\$ 1391(\mathrm{~b}))$, subject, howcrer, to a growing number of exceptions. See, e.g., 60 HARv. L. Rev. 1173 (1947).

${ }^{227}$ See, e.g., Jackson, Full Faith and Credit-The Lauyer's Clatuse of the Constitution, 45 CoL. L. REv. 1, 21-24 (1945). Cf. H. R. 3214, $\$ 1963$ providing for the registration of final judgments of a district court in any other district.

${ }^{238}$ Place of trial would still be subject to change under $\$ 140_{4}(\mathrm{a})$, quoted supra note 28 ; sec also Braucher, supra note 28; Comment, 56 YALE L. J. 1234 (1947). 
called "ventriloquist's dummy to the courts of some particular state"119_because they lack the requisite authority to speak themselves. Erie v. Tompkins ${ }^{120}$ was a necessary corrective of an act of usurpation, ${ }^{121}$ but the federal system will be at its best when federal courts concern themselves primarily with federal law and there is smallest room within the range of their adjudication for the Erie doctrine to apply.

Re-examination of diversity may show, of course, that there are areas within the litigation that it brings to federal tribunals that should be made the subject of substantive federal legislation to be enforced by district courts. This was what happened when reorganization under Section 77 of the Bankruptcy Act supplanted the old equity receivership. Who will deny that the development, with legislation on the substance of the issues, represented an improvement in the law? The interstate interests that normally support diversity jurisdiction because they see advantage in a federal forum are all engaged in interstate commerce; if they have need for federal protection, the Congress sits to hear their case. Taft-Hartley shows what happens when the case is deemed persuasive. The enforcement of collective-bargaining agreements has not only been committed to a federal forum; it has become a right conferred by federal law. There are, as Mr. Justice Jackson has observed, ${ }^{122}$ large fields of lawyer's law awaiting development by Congress under powers too long dormant, such as those conferred by the full faith and credit clause. Much that is now believed to be supported by diversity will in the end and far more reasonably be accomplished in this way.

There is, I think, a solid case for preservation of the jurisdiction in any instance where a concrete showing of state prejudice can be established. ${ }^{123}$ There may be cases, too, where there is need for process that outruns state borders, as in the interpleader under present law. ${ }^{\mathbf{1 2 4}}$ I do not argue that diversity should not be utilized

${ }^{110}$ Richardson v. Commissioner of Internal Revenue, 126 F. $2 \mathrm{~d} 562,567$ (C. C. A. $2 \mathrm{~d}$ 1942). This is not to say that the role can be any different in so far as Congress chooses to adopt state law. It is to say that Congress has no choice in so far as the only basis for its action is the jurisdictional fact of diversity, unaided by any substantive Congressional power. Sce note 8I stipra. Whether substantive federal legislation indicates adoption of state law is, of course, an issue to be faced in terms of the language and policy of the particular enactment. Cf. Vanston Committee v. Green, 329 U. S. 156 (1946). ${ }_{120} 304$ U. S. 64 ( 1938$)$.

131 Those commentators who protest the constitutional language of Mr. Justice Brandeis' opinion seem to me to overlook or to dismiss too lightly the point made supra note Irg. See Frankfurter, J., in Guaranty Trust Co. v. York, 326 U. S. 99, 10I-102 (1945). It does not follow, of course, that every scrap in the state judicial larder must be relished by a federal court. That course will lead inevitably to misapplication of state law, in the strictest sense; for such scraps are often rejected in the state's own courts. See Clark, State Law in the Federal Contrs, 55 YALE L. J. 267, 290-295 (1946); Note, 59 Harv. L. Rev. 1299 (1946).

192 See Jackson, supra note 117 , at $21-23$.

${ }^{125}$ Cf. S. 466, 79th Cong., xst Sess., supra note 98. That such a provision can be meaningful is shown by the opinion of Circuit Judge Taft in City of Detroit v. Detroit City Ry., 54 Fed. I (E. D. Mich. 1893). So long as diversity is retained with general scope there is, however, too little function for the present local-prejudice ground of removal (Judicial Code \$28, 28 U. S. C. \$7I (r940)); and it is properiy abandoned in the bill,

${ }^{126} 28$ U. S. C. $\$_{41}(26)$ (1940); FEd. R. Crv. P., 22; H. R. 3214, 511335 , 1397, 236r; see Chafee, The Federal Interpleader Act of 1936, 45 YALE L. J. 963 (1936); Federal Interpleader Since the Act of 1936,49 YALE L. J. 377 (1940); Bradening the Second Stage of Federdi Interpleader, 56 HaRv. L. Rev. 929 (1943). 
to grant a federal forum on such principles. To do so is to premise federal intervention on a current finding of a state inadequacy. The problem is to limit intervention to the situations where it is in fact responsive to such need.

A program of this kind does not, it must be recognized, present solid political attraction. No major economic interest now feels outraged by diversity jurisdiction, as in the days when it was portion of the target in labor's fight against the federal injunction. And Erie v. Tompkins operates to keep down deep resentment founded on the overt nullification of state law. ${ }^{125}$ Support must come, therefore, from the disinterested sources, the judiciary and the bar-including the law members of the Congress-content to view the issue in its right dimension as a problem of the uses of the federal courts. Such support may be forthcoming at a time when there is widespread interest in the organization of the federal government and the surrender of unnecessary functions now in federal hands.

Short of this major operation on diversity, there are, it seems to me, two smaller steps that should be taken promptly. The first is to revive Attorney General Mitchell's bill, proposed by President Hoover, to treat a corporation as a citizen of any state in which it is engaged in business for purposes of measuring diversity in its controversies with the residents of such a state. ${ }^{126}$ This would remove the largest portion of the corporate anomaly. The second is to vest in district courts discretion to refuse adjudication whenever they find state law too uncertain to justify its application in a case that is not subject to the state appellate review. The Supreme Court has held against existence of discretion of this order, apart from cases covered by the special equitable doctrines, perceiving a compulsion to decision in the statutory grant of jurisdiction. ${ }^{127}$ The compulsion ought to be removed. If'federal courts are to engage in state administration, they should at least be free to abdicate the function when insufficient tools for its performance are at hand. ${ }^{128}$

\section{V \\ Rules of Decision}

The statutory mandate on state laws as rules of decision, ${ }^{120}$ deriving from the first Judiciary Act, is limited in terms to "trials at common law." The bill would

- ${ }^{125}$ Cf. Sen. Rep. No. 530, 72d Cong., ist Sess. (1932).

- ${ }^{120}$ S. 937, 72d Cong., rst Sess. (1932); SEN. Doc. No. 65, 72d Cong., 1st Sess. (1932). For earlier precedents, sce Felix Frankfurter and James M. Landis, The Business of the Supreme Court $136-145$ (1927).

The present bill ( $\$ 399(c)$ ) provides that a "corporation may be sued in any judicial district in which it is incorporated or licensed to do business or is doing business, and such judicial district shall be regarded as the residence of such corporation for venue purposes." The result reached in Neirbo Co. v. Bethlehem Shipbuilding Corp., 308 U. S. 165 (1939), where the corporation is defendant, will thus no longer be dependent on consent to suit required by state law. More significantly, when the corporation is a plaintiff it will be able in diversity cases to lay venue in any district in which it docs business.

$\ldots 127$ Meredith v. Winter Háven, 320 U. S. 228 (1943).

128 This would go far to meet the danger that state lower court doctrines, destined for extinction when the issue finally is faced on high, will in the meantime be the basis of irrevocable adjudication in the district courts. 'Seé "Clark, stepra note 121 , at' 292 . The utility of the principle in other fields is indicated: by Thompson v. Magnolia Co., 309 U. S. 478 (1940).

${ }^{229}$ ReV. STAT. \$72I, 28 U. S. C. \$725 (I940). 
properly extend it to all "civil actions,"130 for this is necessarily the situation. In so far as rights and duties have not been created by the federal law they must, if they exist at all, derive their being from state sources. The question when creation of such rights or duties is committed to the action of the federal judiciary is unaffected by the pending measure, which retains the substance of the vital qualifying language: state laws govern only in the "cases where they apply," and "except where the constitution, treaties or statutes of the United States shall otherwise require or provide." Erie v. Tompkins focuses attention with progressive emphasis on the meaning of these qualifications. The judicial exploration of that aspect of the problem ${ }^{131}$ now points the way to further clarifying legislation within a portion of the field.

To a remarkable extent the federal substantive law defines powers without attention to resulting liabilities and prescribes rights and duties without also providing for their vindication or their breach. There is always room for question, therefore, whether Congress meant to relegate these matters to determination by the application of state legal systems or assumed, on the contrary, that the gloss would come from interstitial legislation of the federal courts, based upon their grant of jurisdiction. It seems plain now that the presumption is in favor of the federal judiciary in cases where the remedy invoked is equitable. ${ }^{132}$ There may be more uncertainty where what is sought would formerly have been relief at law. ${ }^{133}$ In neither case, however, should the answer be left merely to an implication; nor should the states provide the governing rule--unless the Congress has made clear in the particular area an intention to refer questions of remedies to state law..$^{\mathbf{1 3 4}}$

There should, therefore, be a companion section to that dealing with state laws as rules of decision. It should provide that for enforcement of all federal rights and duties the federal courts are authorized to grant all remedies afforded by the principles of law, unless an Act of Congress otherwise requires or provides. This would eliminate all doubt that courts of the United States administer a wholly federal jurisprudence in so far as they are dealing with the remedial consequences of the federal law, except in concrete situations where the Congress has provided otherwise. Within this area of federal jurisprudence, federal decisional doctrine would, of course, be binding on state courts when they administer the national law. This seems to be the plain intendment of the recent Supreme Court decisions. ${ }^{135}$ The

${ }^{130}$ H. R. $3214, \$ 1652$.

${ }^{131}$ See, e.g., Holmberg v. Armbrecht, 327 U. S. 392 (1946); Bell v. Hood, 327 U. S. 678 (r946); Guaranty Trust Co. v. York, 326 U. S. 99 (I945); Clearfield Trust Co. v. United States, 3 r8 U. S. 363 (I943); Sola Electric Co. v. Jefferson Electric Co., 3 I7 U. S. 173 (1942); D'Oench, Duhme \& Co. v. F. D. I. C., $3 I_{5}$ U. S. 447 (1942); Deitrick v. Greaney, 309 U. S. r9o (r940); Russell v. Todd, 309 U. S. 280 (1940); Board of Commissioners v. United States, 308 U. S. 343 (I939); of. Note, 32 Col. L. Rev. 688 (1932); Comment, 55 YAIE L. J. 40I (1946); Snepp, The Law Applied in the Federal Courts, this symposium.

${ }^{182}$ See the clarifying analysis in Holmberg v. Armbrecht, supra note 131.

19s $C f$. Bell v. Hood, supra note 13I.

1st For an early effort to cope with the problem generally in an area of federal rights, see REv. STAT. $\$ 722,28$ U. S. C. $\$ 729$ (1940). Cf. H. R. $3214, \$ \$ 1346(b), 2672$ (tort claims against United States).

${ }^{106}$ See note 13I supra; of. Reitmeister v. Reitmeister, 162 F. 2d 691 (C. C. A. 2d 1947); Note, Use of Common-Law Techniques and Remedies in Statutory Enforcement-A Study in Judicial Behavior, 57 HARv. L. REv. 900 (1944). 
doubts that still appear to envelop the issue should, it seems to me, be set at rest.

With this step taken, Congress will be brought to further systematic consideration of the extent to which it wills to leave these issues to a purely judge-made resolution or prefers itself to lay down the resolving rule. Why, for example, should the Code prescribe statutes of limitation for suits against the United States ${ }^{136}$ but none for other situations where the right involved is federal and no special rule of limitations has been prescribed? Why should the federal law be silent as to when a damage action lies against a federal official ${ }^{137}$ and when honest error in reliance on authority constitutes a good defense? ${ }^{138}$ Why should Taft-Hartley leave uncertain the extent to which state rules of contract law are relevant in the enforcement of collective-bargaining agreements in the federal courts? Needless to say, what is involved goes far beyond the issue as to remedies that I have meant to pose. It takes in all the lawyer's law that rarely is articulated but always is assumed when Congress legislates in any special field. To bring this all within the legislative process is a large assignment. But despite the monumental strides of recent years, the nation's law will not have lost its fragmentary quality until the mission is performed.

\section{Conclusion}

The revision of the Code embodies major progress. I have tried to show the measure of the problems that remain. It may be wiser not to jeopardize the passage of the present bill by raising any of these questions. That is a judgment to be made by those who know the legislative situation. I urge no more than that we recognize how much remains undone; and that we undertake to do it when we can.

${ }^{130}$ H. R. 3214 , \$20r.

${ }^{137}$ Bell v. Hood, stipra note 131 .

${ }^{238}$ Cf. De Witt v. Wilcox, r6r F. $2 d 785$ (C. C. A. 9 th 2947 ), cert. denied, 68 Sup. Ct. 68. 


\section{APPENDIX}

Diversity of Citizenship Cases Terminated in 84 United States District Courts During the Frscal Years I942, 1943 and r944, by Nature of Suit and Residence of Parties, Showing the Number and Percentage of Cases in Each Group Which Were Removed from a State Court ${ }^{139}$

\begin{tabular}{|c|c|c|c|c|c|c|c|c|c|c|c|c|c|}
\hline & \multicolumn{4}{|c|}{ :Cases Terminated } & \multirow{2}{*}{ 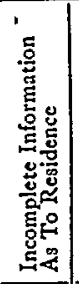 } & \multirow{2}{*}{ 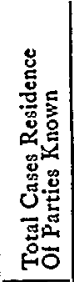 } & \multicolumn{2}{|c|}{$\begin{array}{l}\text { Plaintiff a } \\
\text { Resident }\end{array}$} & \multicolumn{2}{|c|}{$\underset{\text { Refident }}{\text { Defendant a }}$} & \multirow{2}{*}{ 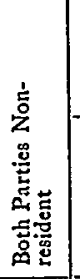 } & \multicolumn{2}{|c|}{$\begin{array}{l}\text { Cases Involving } \\
\text { Non-resident } \\
\text { Corporation } \\
\text { As a Party }\end{array}$} \\
\hline & 1942 & 1943 & 1944 & $\begin{array}{c}\text { Total } \\
3 \\
\text { Years }\end{array}$ & & & 泀事 & 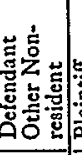 & 蒙 & 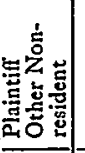 & & $\begin{array}{l}\text { 总 } \\
\text { 音 } \\
\text { z }\end{array}$ & 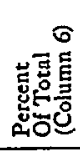 \\
\hline$T A L C$ & 7,786 & 6,344 & 5,447 & 19,577 & $3,47 \hat{s} 1$ & 16,104 & $8,07 \pm$ & 1,636 & 2,164 & $|3,169|$ & 1,061 & 11,299 & 70.2 \\
\hline Removed Cases... & 3,188 & 2,337 & 2,111 & 7,635 & 895 & 6,741 & 5,205 & 947 & 65 & 111 & 413 & 5,683 & 84.3 \\
\hline Percent Removed & $4 v .9$ & 36.8 & 38.8 & 39.0 & 25.8 & 41.9 & 64.5 & 57.9 & 3.0 & 3.5 & 38.9 & 50.3 & \\
\hline Real Proper & 624 & 414 & 325 & $1,363 \mid$ & 367 & 996 & 335 & 100 & 252 & 245 & 64 & 651 & 65.4 \\
\hline Ren & 159 & 122 & 50 & 371 & 75 & 296 & 204 & 58 & 8 & 12 & 14 & 226 & 76.4 \\
\hline Percent Remaved & 25.5 & 29.5 & 27.7 & 27.2 & 20.4 & 29.7 & 60.9 & 58.0 & 3.2 & 4.9 & 21.9 & 34.7 & \\
\hline Insuran & 1,180 & 1,013 & 1,057 & 3,250 & 351 & 2,899 & $1,920 \mid$ & 59 & 711 & 68 & 141 & 2,772 & 95.6 \\
\hline Removed Cases... & 595 & 500 & 569 & 1,664 & 143 & 1,521 & $1,406 \mid$ & 19. & 15 & 4 & 77 & 1,498 & 98.5 \\
\hline Percent Removed & 50.4 & 49.4 & 53.8 & 51.2 & $4 v .7$ & 52.5 & 73.2 & 32.2 & 2.1 & 5.9 & 54.6 & 54.0 & \\
\hline Other $C$ & 1,642 & 1,400 & 1,207 & 4,249 & 996 & 3,253 & $\mid 1,074$ & 324 & 744 & 857 & 254 & 2,072 & 63.7 \\
\hline Cases... & 431 & 323 & 262 & $1,016 \mid$ & 195 & 821 & 592 & 98 & 24 & 24 & 83 & 699 & 85.1 \\
\hline Percent & 26.2 & 23.1 & 21.7 & 23.9 & 19.6 & 25.2 & 55.1 & 30.2 & 3.2 & 2.8 & 32.7 & 33.7 & \\
\hline Motor l'hicle- & & & & & & & & & & & & & \\
\hline Personal Injury..... & 1,992 & 1,535 & 1,130 & 4,657 & 508 & 4,149 & 1,925 & 884 & 79 & 1,030 & 231 & 2,235 & 53.9 \\
\hline Removed Cases... & 1,052 & 660 & 511 & $2,223 \mid$ & 202 & 2,021 & 1,227 & 619 & 7 & 48 & 120 & 1,354 & 67.0 \\
\hline Percent & 52.8 & 43.0 & 45.2 & 47.7 & 39.8 & 48.7 & 63.7 & 70.0 & 8.9 & 4.7 & 51.9 & 60.6 & \\
\hline Other Porson & 1,311 & 1,171 & 1,189 & 3,671 & 480 & 3,191 & 2,238 & 152 & 56 & 504 & 241 & 2,535 & 79.4 \\
\hline Cases... & $7 \times 2$ & 554 & 537 & 1,793 & 187 & 1,606 & $\mid 1, \pm 03$ & 96 & 9 & 15 & 83 & 1,495 & 93.1 \\
\hline Percent Removed & 53.5 & 47.3 & 45.2 & 48.8 & 39.0 & $50 . \hat{3}$ & 62.7 & 63.2 & 16.1 & 3.0 & 34.4 & 59.0 & \\
\hline Other Tor & 522 & 450 & 313 & 1,285 & 275 & 1,010 & 455 & 80 & 129 & 270 & 76 & 660 & 65.3 \\
\hline Remov & 188 & 141 & 119 & 448 & 70 & 378 & 311 & 35 & 2 & 6 & 24 & 337 & 89.2 \\
\hline Percenc Removed. & 36.0 & 31.3 & 38.0 & 34.9 & 25.5 & 37.4 & 68.4 & 43.8 & 1.6 & 2.2 & 31.6 & 51.1 & \\
\hline All Other $D$ & 515 & 361 & 226 & $\mid 1,102$ & 496 & 6.6 & 127 & 37 & 193 & 195 & 54 & 374 & 61.7 \\
\hline Remo & 61 & 37 & 23 & 121 & 23 & 98 & 62 & 22 & $\cdots$ & 2 & 12 & 74 & 75.5 \\
\hline Pereen & 11.8 & 10.2 & 10.2 & 11.0 & 4.6 & 16.2 & 2.48 .8 & 59.5 & . & 1.0 & 22.2 & 19.8 & \\
\hline
\end{tabular}

${ }^{130}$ This table was made available by the Administrative Office in response to a request for information on the working of diversity jurisdiction. 
- 